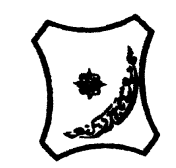

Bayero Journal of Pure and Applied Sciences, 12(2): 40 - 48

Received: September, 2019

Accepted: December, 2019

ISSN $2006-6996$

\title{
AN EVALUATION OF THE CRITICAL FACTORS INFLUENCING PRODUCTIVITY OF MASONRY WORK IN CONSTRUCTION SITES IN KANO, NIGERIA
}

\author{
${ }^{1}$ Jibril, J. D. and ${ }^{2}$ Mukarram, M. A. \\ ${ }^{1}$ Department of Estate Management, Bayero University, Kano Nigeria. \\ ${ }^{2}$ Department of Civil Engineering, Bayero University, Kano Nigeria. \\ Correspondence Author: muhdmukarram@gmail.com
}

\begin{abstract}
Construction labour productivity is of great interest to practitioners and researchers because it affects the performance and success of the project. This research assesses and ranks factors that critically influenced productivity of masonry work for some selected projects within Kano metropolis, Nigeria. A total of sixty three (63) respondents which include construction experts from lower to top management levels of various positions were selected. Structured questionnaire related to masonry labour and productivity was distributed to the selected respondents. The four most critical factors that negatively influence labour productivity of masonry as identified by the respondents work were found to be delayed in payment process. Payment process discourages some qualified contractors from bidding for the job, material quantity which result in stoppage of material delivery, security of life and property. Security as a constraint has negative and significant influence on the program of projects and worker experience. Lack of labour experience has a very high effect on productivity; experience improves both intellectual and physical abilities that improve productivity. The inferences drawn from this study could be used by the project managers to take account of these factors at an early stage in order to improve labour productivity of workers on construction site in Nigerian.
\end{abstract}

Keywords: Construction sites, Critical factors, Masonry work, Labour Productivity

\section{INTRODUCTION}

The construction industry is known to be the largest industry in Nigeria, employing a good proportion of the work force and controlling over $50 \%$ of the Nation's Gross National Product (Fagbeleet el., 2011). Unfortunately, many workers have lost their employment and embargoes have been placed on employment in both public and private sector due to the long economic problem which lasted for more than a decade. Within this period, the leadership of the country had changed hands fourteen times. Each regime comes with different strategies of solving the economic problems. Therefore, the few workers (labour) that remain in the construction industry need to be properly managed if performance is to improve. (Fagbeleet el.,2011). Labour is defined as a task that requires the exertion of body and mind or both. It is also regarded as an important resource in construction because it is the one that combines all the other resources namely: materials, plant equipment and finance in order to produce various construction products (Gide, 2011).

According to Nunnaly (2005), the term productivity means the output of the construction goods and services per unit of labour input.The labour force can be broadly categorized into; skilled labour or craftsmen and unskilled labour. The staff under the skilled labour is of varying abilities ranging from apprentices to trade foremen or supervisors. The apprentice can be described as a beginner who is willing and interested in learning a certain trade in the construction industry. The three possible avenues of training this category of people are the school, the workshop and the field (Ojo, 2009). Some of the craftsmen in this category are carpenters, masons/bricklayers, electricians, plumbers, painters, crane drivers, steel fixers, tile setters and etcetera. The unskilled labour on the other hand is a category of workers that requires no special skill and it is defined as any way of making a living with little or no degree of security of income and employment. However, they require little or no training to make them perform. Certainly, the unskilled labourers are able-bodied men and women that perform manual duties. Their major asset, therefore, lies in their strength with a healthy body (Ojo, 2009). 
BAJOPAS Volume 12 Number 2, December, 2019 Understanding the productivity of masons is important for management of building projects that involve masonry works. The masonry process is perceived to be one of the labour intensive aspects of construction process from time immemorial as claimed by Chudley and Greeno (2005). Productivity of masons is measured in terms of area in square metres of block/brick work built by a single mason per unit of time preferably a day, normally eight (8) hours of work (Nalumansi and Mwesige, 2012). According to Abdel-Razek et al., (2006), construction industry involves a large number of variables: the labour intensive work, the unique character and the occurrence of unpredictable events. The construction process results in relatively high costs and labour becomes a more important input in the production phase. Moreover, the labour cost is somewhere between $20 \%$ and $50 \%$ of the total project cost and the reduction of these costs can be best carried out by improving productivity (Gambao, et al., 2000).

According to Polat et al., (2005), policies for increasing productivity is not necessarily the same in every country and this means that critical factors in developing countries differs from that of developed countries. In order to improve productivity, a study of the factors affecting it, whether positively or negatively, is necessary (Abdullahi, 2010). Many factors can be used to measure productivity. For example, managers can generate diverse productivity data that take into account the measured productivity and the factors that influence it. These data can then be used to define an index for measuring the performance of a project, which in turn plays an important role in decision making during the project engineering process.(Yu \& Lee, 2002). Based on the previous researches, 40 factors that affect construction labour have been identified and were categorized into four (4) groups according to their characteristics in relation to economic and social environment. These factors are:

i. Material/Tools components (6 factors)

ii. Worker components (12 factors)

iii. Work characteristic components factors)

iv. Management and control components (15 factors).

These factors were used as a basis for preparing quantitative surveys in order to investigate the influence of such factors on the productivity of masonry work in construction site. These components were then further classified into those that directly influence labour productivity (workers group) and those that indirectly influence labour productivity by influencing the works of the workers (the works characteristics, materials and management and control groups). The changing nature of factors influencing labour productivity of various trades on construction sites is not very clear especially in Kano, Nigeria. This negatively affects the accuracy of the labour constants commonly used for estimating labour costs in this part of the country. If all factors influencing productivity are known, it will be possible to forecast productivity with optimum accuracy. The result of various studies related to this topic indicates a need for systematic classification and definition of various factors that are directly or indirectly influencing productivity of labour in various trades so as to establish a strategy and action plan for managing labour productivity particularly, masonry work on construction sites (Nalumansi and Mwesige, (2012). The study is aimed at evaluation factors that influence productivity of masonry work with a view to improving labour productivity of workers on site. This research work, therefore, studied the factors that influence productivity of masonry work at different small and medium construction sites within Kano metropolis. Kano metropolis comprises of eight (8) local governments, namely: Dala, Fagge, Gwale, Kano municipal council, Kumbotso, Nassarawa, Tarauni and Ungogo.

\section{MATERIALS AND METHODS}

This study is based on a survey designed to gather all necessary information in an effective way. The survey presents thirty seven (37) productivity factors which were generated on the basis of related previous research work on construction productivity, alongside input, revision and modification from local experts. The factors were divided into four (4) components based on the previous literature and as suggested by local experts.

In this study, five (5) Likert scale measurement was used to determine the degree of influence of these factors on masonry productivity. This study was carried out within Kano metropolitan area in Nigeria. Data sets were collected from various construction projects for the purpose of this research. Kano is located in the Northwestern Nigeria. The city has a population of about 20 million people (in 2008 census) and it is hosting numerous construction companies operating in Nigeria. The population (N) of interest considered in respect of this study were eighty (80) "construction experts and labour operatives" as they are within the scope of this study. The construction experts constitute mostly the contractors, project managers, site engineers, project supervisors and the likes. 
BAJOPAS Volume 12 Number 2, December, 2019 This is because they are directly involved in the construction of a residential, industrial, and commercial buildings for both public and private owners. The research also captured some relevant profile information of the population of interest.

For the purpose of this study, a structured closed ended questionnaire was used for the data gathering. The questionnaire was designed to capture the background information of the respondents and the factors that affect labour productivity of masonry work on construction site. This is imperative as it will go a long way in clearly assessing how such factors critically influence labour productivity of masonry work in the study area. The questionnaire was designed in a simple format taking into consideration the research objectives. The research questionnaire was divided into two (2) sections, that is, section $A$ and $B$. Section ' $A$ ' of the research questionnaire captured the respondents' profile and background information. Section ' $\mathrm{B}$ ' contained the nature of masonry projects being undertaken as it will help in assessing the factors that critically influence the productivity of masonry work in construction sites. It will equally assist in evaluating the factors that influence productivity of masonry work in construction sites.

Respondents from the contractors and operators were asked to rank the factors which they considered as being negatively affecting the performance of their masonry labour on sites. The illiterate/semi-illiterate respondents among the labour were however guided by reading out

\section{RESULTS AND DISCUSSION}

As a result of the field survey and follow up, a total of 63 out of 80 questionnaires were completed and returned from various survey the questions to them and their responses by carefully filled-in. Using Likert statistical technique on a scale of 1 to 5 , the relative index (RI) was calculated using the following formula (Lim et al., 1995).

\section{Relative Importance Index $=$ $5 n^{5}+4 n^{4}+3 n^{3}+2 n^{2}+n^{1}$ $\mathbf{5}\left(\mathbf{n}^{5}+\mathbf{n}^{4}+\mathbf{n}^{3}+\mathbf{n}^{2}+n^{1}\right)$}

Where; (5- affects with "very high effect"; 4affects "High effects"; 3- affects with "average effect"; 2 -affects with "Some effect"; and 1affects with "Little effect").

The respondents were then asked to rate the frequency of occurrence of each factor according to three ordinal scales: High (3), Medium (2), or Low (1). The "Frequency Index" for each factor was derived from the following formula:

\section{Frequency Index $=\frac{3 n^{3}+2 n^{2}+n^{1}}{3\left(n^{3}+n^{2}+n^{1}\right)}$}

Where $n^{3}$ is the number of respondents who answered "High", $n^{2}$ is the number of respondents who answered "Average"; and $n^{1}$ the number of respondents who answered "Low".

Finally, an overall index which is the multiplication of "Relative Importance Index" by the "Frequency Index" was named the "Severity/Critical Index". The severity Index was used to rank the overall implication of each factor on labour productivity for masonry work. "Severity/Critical Index" = "Relative Importance index" $x$ "Frequency Index".

areas in Kano metropolis as depicted in table 1. A close personal contact with respondents was used due to the number of items in the questionnaire distributed.

Table 1: Survey Area

\begin{tabular}{lcc}
\hline Area & Frequency (N) & Percentage (\%) \\
\hline Dala L.G.A & 5 & 8 \\
Fagge L.G.A & 7 & 11 \\
Gwale L.G.A & 17 & 27 \\
Kano municipal L.G.A & 3 & 5 \\
Kumbotso L.G.A & 4 & 6 \\
Nassarawa L.G.A & 9 & 14 \\
Tarauni L.G.A & 12 & 19 \\
Ungogo L.G.A & 6 & 10 \\
Total & 63 & 100 \\
\hline
\end{tabular}

Table 2: Number of Respondents

\begin{tabular}{ccc}
\hline Questionnaire & Frequency (N) & Percentage (\%) \\
\hline Returned & 63 & 79 \\
Not returned & 17 & 21 \\
Total & 80 & 100 \\
\hline
\end{tabular}


BAJOPAS Volume 12 Number 2, December, 2019

Table 3: Position/Rank of the Respondent

\begin{tabular}{lcc}
\hline Position/Rank & Frequency (N) & Percentage (\%) \\
\hline Top management level & 21 & 33 \\
Middle Mgt. level & 10 & 16 \\
Low Mgt. Level & 3 & 5 \\
Operatives & 29 & 46 \\
Total & 63 & 100 \\
\hline
\end{tabular}

Table 3 shows the categories of the respondents from contractors at top management level $(33 \%)$ middle and low management levels (21\%) to site operators (46\%).

\begin{tabular}{lcc} 
Table 4: Years of Working Experience & \\
\hline Years & Frequency (N) & Percentage (\%) \\
\hline Less than & 0 & 0 \\
$6-10$ & 6 & 10 \\
$11-15$ & 4 & 6 \\
$16-20$ & 9 & 14 \\
$21-25$ & 24 & 38 \\
More than 25 & 20 & 32 \\
Total & 63 & 100 \\
\hline
\end{tabular}

Table 4- 10 shows that majority of the respondents $(90 \%)$ have working experience of more than ten (10) years. Furthermore, over

$(10 \%)$ of the respondents have working experience of more than five (5) years in various building projects, particularly masonry work.

Table 5: Type of Client

\begin{tabular}{ccc}
\hline Client & Frequency (N) & Percentage (\%) \\
\hline Public & 6 & 9 \\
Private & 8 & 13 \\
Both & 49 & 78 \\
Total & 63 & 100 \\
\hline
\end{tabular}

Table 6: Annual Turn Over

\begin{tabular}{lcc}
\hline Turn over & Frequency $\mathbf{( N )}$ & Percentage (\%) \\
\hline Up to $10 \mathrm{~m}$ & 4 & 6 \\
$10-100 \mathrm{~m}$ & 9 & 14 \\
$100-300 \mathrm{~m}$ & 23 & 37 \\
Over $300 \mathrm{~m}$ & 27 & 43 \\
Total & 63 & 100 \\
\hline
\end{tabular}

Table 7: Type of Construction/Project Undertaken

\begin{tabular}{lcc}
\hline Project & Frequency (N) & Percentage (\%) \\
\hline Building works & 41 & 65 \\
Civil Engineering works & 5 & 8 \\
Both & 13 & 21 \\
Others & 4 & 6 \\
Total & 63 & 100 \\
\hline
\end{tabular}

Table 8: Type of Building Project Undertaken

\begin{tabular}{lcc}
\hline Project & Frequency (N) & Percentage (\%) \\
\hline Bungalow & 19 & 30 \\
$1-3$ store building & 33 & 52 \\
More than 3 storey bldg. & 11 & 18 \\
Total & 63 & 100 \\
\hline
\end{tabular}


BAJOPAS Volume 12 Number 2, December, 2019

Table 9: Type of Masonry Work Undertaken

\begin{tabular}{lcc}
\hline Masonry work & Frequency $(\mathbf{N})$ & Percentage (\%) \\
\hline Block work & 31 & 49 \\
Brick work & 9 & 14 \\
Both & 23 & 37 \\
Total & 63 & 100 \\
\hline
\end{tabular}

Table 10:Masonry Content

\begin{tabular}{lcc}
\hline Work content & Frequency (N) & Percentage (\%) \\
\hline High work content & 37 & 59 \\
Medium work content & 18 & 28 \\
Low work content & 8 & 13 \\
Total & 63 & 100 \\
\hline
\end{tabular}

\section{Results from Factors Ranking}

In this article, Forty (40) related factors that negatively influence productivity have been identified and ranked according to their critical influence on masonry labour.

\section{Worker Group}

Table 11 shows the ranking of twelve (12) factors in the group. The result indicated that the most important factors that negatively influence productivity of masonry worker are: security (0.905), worker experience (0.873), worker communication (0.835), worker motivation (0.798), worker expertise (0.790), worker health (0.756) and worker training (0.704). Other factors are: worker education $(0.687)$, team work $(0.638)$, worker sense of responsibility $(0.556)$, worker capability $(0.502)$, worker morale and attitude (0.479).

Table 11; Factors Under Worker Group

\begin{tabular}{|c|c|c|c|c|c|c|c|c|}
\hline \multirow{2}{*}{ Related factors } & \multicolumn{5}{|c|}{ Degree of importance } & \multirow[t]{2}{*}{ Total resp. } & \multirow[t]{2}{*}{ RII Index } & \multirow[t]{2}{*}{ Rank } \\
\hline & 5 & 4 & 3 & 2 & 1 & & & \\
\hline Security & 43 & 11 & 8 & 1 & 0 & 63 & 0.905 & $1^{\mathrm{st}}$ \\
\hline Worker experience & 39 & 14 & 6 & 2 & 2 & 63 & 0.873 & $2^{\text {nd }}$ \\
\hline Worker communication & 31 & 18 & 6 & 7 & 4 & 63 & 0.835 & $3^{\text {rd }}$ \\
\hline Worker motivation & 23 & 19 & 19 & 1 & 1 & 63 & 0.798 & $4^{\text {th }}$ \\
\hline Worker expertise & 21 & 24 & 16 & 2 & 0 & 63 & 0.790 & $5^{\text {th }}$ \\
\hline Worker health & 25 & 17 & 8 & 8 & 5 & 63 & 0.756 & $6^{\text {th }}$ \\
\hline Worker training & 18 & 12 & 21 & 9 & 3 & 63 & 0.704 & $7^{\text {th }}$ \\
\hline Worker education & 16 & 13 & 20 & 10 & 4 & 63 & 0.687 & $8^{\text {th }}$ \\
\hline Team work & 11 & 12 & 24 & 10 & 6 & 63 & 0.638 & $9^{\text {th }}$ \\
\hline Worker sense of responsibility & 7 & 23 & 10 & 5 & 8 & 63 & 0.556 & $10^{\text {th }}$ \\
\hline Worker capability & 11 & 7 & 8 & 14 & 23 & 63 & 0.502 & $11^{\text {th }}$ \\
\hline Worker morale and attitude & 6 & 11 & 2 & 27 & 17 & 63 & 0.479 & $12^{\text {th }}$ \\
\hline \multicolumn{4}{|c|}{$\begin{array}{l}\text { aterial/Tools Group } \\
\text { ble } 12 \text { shows the ranking of six (6) factors in } \\
\text { group. The result indicated that the most } \\
\text { portant factors that negatively influence } \\
\text { oductivity of masonry work are: material } \\
\text { ble 12: Factors Under Material/Tools Group }\end{array}$} & \multicolumn{5}{|c|}{$\begin{array}{l}\text { quantity }(0.937) \text {, material condition }(0.89 \\
\text { tools and equipment shortage }(0.771) \text {, mate } \\
\text { transportation }(0.737) \text {, material procurem } \\
(0.565) \text {, and material applicability }(0.559) \text {. }\end{array}$} \\
\hline \multirow{2}{*}{ lated factors } & \multicolumn{5}{|c|}{ Degree of importance } & Total resp. & RII Index & Rank \\
\hline & 5 & 4 & 3 & 2 & 1 & & & \\
\hline II & 49 & 8 & 6 & 0 & 0 & 63 & 0.937 & $1^{\text {st }}$ \\
\hline Iditi & 38 & 19 & 4 & 1 & 1 & 63 & 0.892 & $2^{\text {nd }}$ \\
\hline and equipment shortage & 22 & 15 & 21 & 5 & 0 & 63 & 0.771 & $3^{\text {rd }}$ \\
\hline rial transportation & 26 & 15 & 8 & 4 & 10 & 63 & 0.737 & $4^{\text {th }}$ \\
\hline rial procurement & 13 & 9 & 6 & 20 & 19 & 63 & 0.565 & $5^{\text {th }}$ \\
\hline erial applicability & 15 & 0 & 18 & 17 & 13 & 63 & 0.559 & 6th \\
\hline
\end{tabular}


BAJOPAS Volume 12 Number 2, December, 2019

Worker Characteristics Group

In this group, the result shows that among the seven (7) most important factors that negatively influence productivity of masonry work are: work space $(0.867)$, poor weather condition
(0.800), work difficulty (0.673), work environment (0.654), working field accessibility $(0.609)$, work quality $(0.448)$, and work method (0.321) as depicted in table 13 below.

Table 13: Factors Under Work Characteristics Group

\begin{tabular}{llllllllll}
\hline Related factors & \multicolumn{1}{c}{ Degree of importance } & Total resp. & RII Index & Rank \\
\cline { 2 - 10 } & 5 & 4 & 3 & 2 & 1 & & & \\
Work space & 38 & 19 & 4 & 1 & 1 & 63 & 0.867 & $1^{\text {st }}$ \\
Poor weather condition & 27 & 21 & 8 & 2 & 5 & 63 & 0.800 & $2^{\text {nd }}$ \\
Work difficulty & 15 & 7 & 29 & 10 & 2 & 63 & 0.673 & $3^{\text {rd }}$ \\
Work environment & 5 & 23 & 27 & 0 & 8 & 63 & 0.654 & $4^{\text {th }}$ \\
Working field accessibility & 18 & 2 & 20 & 11 & 12 & 63 & 0.609 & $5^{\text {th }}$ \\
Work quality & 3 & 2 & 23 & 14 & 21 & 63 & 0.448 & $6^{\text {th }}$ \\
Work method & 0 & 0 & 14 & 10 & 39 & 63 & 0.321 & 7 th \\
\hline
\end{tabular}

\section{Management and Control Group}

Table 14 shows the ranking of fifteen (15) factors in the group. The result indicated that the most important factors that negatively influence productivity of masonry work are: payment delay (0.946), drawing and specification alteration during project execution $(0.816)$, poor scheduling and coordination $(0.803)$, work order $(0.765)$, slow local authority approval (0.733), lack of periodic meeting with workers (0.619), safety/accident (0.600), rework due to construction error (0.581) and manager capability (0.565). Other factors are: inspection delay (0.559), lack of labour surveillance (0.537), work delay (0.533), management system (0.463), information technology (0.425), and work continuity (0.416).

Table 14: Factors Under Management and Control Group

\begin{tabular}{llllllllll}
\hline \multicolumn{1}{c}{ Degree of importance } & & & & & Total resp. & RII Index & Rank \\
\hline Payment delay & $\mathbf{5}$ & $\mathbf{4}$ & $\mathbf{3}$ & $\mathbf{2}$ & $\mathbf{1}$ & & & \\
Drawing and specification & 50 & 9 & 4 & 0 & 0 & 63 & 0.946 & $1^{\text {st }}$ \\
during project execution & 32 & 17 & 6 & 3 & 5 & 63 & 0.816 & $2^{\text {nd }}$ \\
Poor scheduling and coordination & 25 & 21 & 10 & 7 & 0 & 63 & 0.803 & $3^{\text {rd }}$ \\
Work order & 21 & 16 & 20 & 6 & 0 & 63 & 0.765 & $4^{\text {th }}$ \\
Slow local authority approval & 19 & 7 & 28 & 6 & 3 & 63 & 0.733 & $5^{\text {th }}$ \\
Lack of periodic meeting with workers & 12 & 9 & 20 & 17 & 5 & 63 & 0.619 & $6^{\text {th }}$ \\
Safety/ accident & 9 & 14 & 18 & 12 & 10 & 63 & 0.6 & $7^{\text {th }}$ \\
Rework sdue to construction error & 8 & 12 & 16 & 20 & 7 & 63 & 0.581 & $8^{\text {th }}$ \\
Manager capability & 12 & 5 & 16 & 20 & 10 & 63 & 0.565 & $9^{\text {th }}$ \\
Inspection delay & 8 & 8 & 17 & 23 & 7 & 63 & 0.559 & $10^{\text {th }}$ \\
Lack of labour surveillance & 11 & 3 & 19 & 15 & 15 & 63 & 0.537 & $11^{\text {th }}$ \\
Work delay & 2 & 15 & 15 & 22 & 9 & 63 & 0.533 & $12^{\text {th }}$ \\
Management system & 0 & 11 & 13 & 24 & 15 & 63 & 0.463 & $13^{\text {th }}$ \\
Information technology & 0 & 2 & 20 & 25 & 16 & 63 & 0.425 & $14^{\text {th }}$ \\
Work continuity & 0 & 0 & 25 & 18 & 20 & 63 & 0.416 & $15^{\text {th }}$ \\
\hline
\end{tabular}


BAJOPAS Volume 12 Number 2, December, 2019

Table 15: Overall Factors

\begin{tabular}{|c|c|c|}
\hline Related Factors & RII & RANK \\
\hline Payment delay & 0.946 & 1 \\
\hline Material quantity & 0.937 & 2 \\
\hline Worker experience & 0.905 & 3 \\
\hline Material condition & 0.892 & 4 \\
\hline Security & 0.873 & 5 \\
\hline Work space & 0.867 & 6 \\
\hline Worker communication & 0.835 & 7 \\
\hline $\begin{array}{l}\text { Drawing and specification alteration } \\
\text { during project execution }\end{array}$ & 0.816 & 8 \\
\hline Poor scheduling and coordination & 0.803 & 9 \\
\hline Poor weather condition & 0.800 & 10 \\
\hline Worker motivation & 0.798 & 11 \\
\hline Worker expertise & 0.790 & 12 \\
\hline Tools and equipment shortage & 0.771 & 13 \\
\hline Work order & 0.765 & 14 \\
\hline Worker health & 0.756 & 15 \\
\hline Material transportation & 0.737 & 16 \\
\hline Slow local authority approval & 0.733 & 17 \\
\hline Worker training & 0.704 & 18 \\
\hline Worker education & 0.687 & 19 \\
\hline Work difficulty & 0.673 & 20 \\
\hline Work environment & 0.654 & 21 \\
\hline Team work & 0.638 & 22 \\
\hline Lack of periodic meeting with workers & 0.619 & 23 \\
\hline Working field accessibility & 0.609 & 24 \\
\hline Safety/ accident & 0.600 & 25 \\
\hline Rework due to construction error & 0.581 & 26 \\
\hline Manager capability & 0.565 & 27 \\
\hline Inspection delay & 0.559 & 28 \\
\hline Worker sense of responsibility & 0.546 & 29 \\
\hline Lack of labour surveillance & 0.537 & 30 \\
\hline Work delay & 0.533 & 31 \\
\hline Material applicability & 0.529 & 32 \\
\hline Material procurement & 0.515 & 33 \\
\hline Worker capability & 0.502 & 34 \\
\hline Worker morale and attitude & 0.479 & 35 \\
\hline Management system & 0.463 & 36 \\
\hline Work quality & 0.448 & 37 \\
\hline Information technology & 0.425 & 38 \\
\hline Work continuity & 0.416 & 39 \\
\hline Work method & 0.321 & 40 \\
\hline
\end{tabular}

The ten (10) most frequent factors that negatively affect productivity of masonry work, as revealed by the respondents, could be found in table 16 below:

Table 16: Frequency Index

\begin{tabular}{lcccccc}
\hline Related Factors & $\mathbf{3}$ & $\mathbf{2}$ & $\mathbf{1}$ & Total resp. & Freq. Index & Rank \\
\hline Payment delay & 50 & 13 & 0 & 63 & 0.931 & 1 \\
Material quantity & 49 & 14 & 0 & 63 & 0.926 & 2 \\
Security & 43 & 19 & 1 & 63 & 0.894 & 3 \\
Material condition & 38 & 23 & 2 & 63 & 0.857 & 4 \\
Worker experience & 39 & 20 & 4 & 63 & 0.852 & 5 \\
Work space & 38 & 19 & 6 & 63 & 0.836 & 6 \\
Drawing and specification alteration & 32 & 23 & 8 & 63 & 0.794 & 7 \\
Worker communication & 31 & 24 & 8 & 63 & 0.788 & 8 \\
Poor scheduling & 27 & 29 & 7 & 63 & 0.741 & 9 \\
Poor weather condition & 25 & 21 & 7 & 63 & 0.656 & 10 \\
\hline
\end{tabular}

The ten (10) most critical factors that negatively affect productivity of masonry work were presented in table 17 below: 
BAJOPAS Volume 12 Number 2, December, 2019

Table 17: Critical Index

\begin{tabular}{lcccc}
\hline Related Factors & $\begin{array}{c}\text { Relative Important } \\
\text { Index }\end{array}$ & $\begin{array}{c}\text { Frequency } \\
\text { Index }\end{array}$ & $\begin{array}{c}\text { Critical } \\
\text { Index }\end{array}$ & Rank \\
\hline Payment delay & 0.946 & 0.931 & 0.881 & 1 \\
Material quantity & 0.937 & 0.926 & 0.868 & 2 \\
Security & 0.905 & 0.873 & 0.809 & 3 \\
Worker experience & 0.892 & 0.857 & 0.764 & 4 \\
Material condition & 0.873 & 0.852 & 0.744 & 5 \\
Work space & 0.867 & 0.836 & 0.725 & 6 \\
Worker communication & 0.835 & 0.794 & 0.658 & 7 \\
Drawing and specification & 0.816 & 0.788 & 0.647 & 8 \\
alteration & & & & \\
Poor weather condition & 0.803 & 0.741 & 0.593 & 9 \\
Poor project scheduling & 0.800 & 0.656 & 0.526 & 10 \\
\hline
\end{tabular}

\section{CONCLUSION}

This research has identified evaluates and ranked factors that were found to be of critical influence on labour productivity for masonry work on site. The results of the research iv indicated that the top four (4) factors that critically influence labour productivity of masonry work were; payment delay, material quantity, security, material condition and worker experience.

i. Payment delay (financial problem), (Critical Index $=0.881$ ): Payment process discourages some qualified contractors from bidding for the job. In some cases, payment process is exposed to corruption. Payment delay can influence the supplier not to deliver adequate material to the site.

ii. Material quantity (delivery), (Critical index $=0.868)$ : The second most critical factor with negative effect on labour productivity of masonry work is the stoppage of material delivery.

a. Material can be short on site due to supplier's attitude as a result of nonpayment from the part of the main contractors. This makes the suppliers to have no confidence on the contractors.

b. Lack or shortage of material on site results in the workers being idling and doing nothing and this would influence the workers' motivation and productivity.

iif. Security, (Critical Index $=0.809$ ): This is the third ranked critical factor that negatively influences productivity of masonry work. Security as a constraint has negative and significant influence on the

\section{REFERENCES}

Abdel-Razek, R., AbdElshakour, H. and AbdelHamid, A. (2006). Labour productivity: benchmarking and variability in Egyptian projects. International Journal of Project Management, 25: 189-197. program of projects. The ranking of this factor by the respondents may be connected to the current security challenges facing Kano and other part of northern Nigeria.

Worker experience, (Critical Index = 0.764): This is the fourth critical factor ranked by the respondents as it negatively influences productivity of masonry work. Lack of labour experience has a very high effect on productivity. The finding of this study was also supported by some research which confirmed that experience of workforce affects job site productivity. Experience improves both intellectual and physical abilities which eventually improve productivity.

\section{RECOMMENDATIONS}

From the findings of this study, the following recommendations were made;

i. Payment delay: Payment should be made promptly to both contractors and suppliers for efficient project delivery.

ii. Material quantity: The procurement department should always coordinate with site staff to ensure adequate material supply to site.

iii. Security: Government should provide adequate security of life and properties to its citizens as this will improve productivity.

iv. Worker experience: On-site training, seminars, conferences, and workshops should be encouraged for workers as this would go a long way in skills enhancement.

Abdullahi, M. (2010). Empirical determination of labour outputs for selected trades in Kaduna State, Unpublished B.Sc. Thesis, Department of Quantity Surveying, Ahmadu Bello University, Zaria. 
BAJOPAS Volume 12 Number 2, December, 2019

Chudley R. and Greeno R. (2005). Construction technology, 6th edition, USA: Pearson and Longman.

Fagbele, O. I, Ogunde, A. O. and Owolabi J. D (2011). Factors affecting the performance of labour in Nigerian construction sites. Mediterranean Journal of Social Sciences, 2(2): 251- 7.

Gambao, E., Balaguer, C. and Gebhart, F. (2000). Robot assembly system for computer-integrated construction. Automation in Construction, 9: 479-487.

Gide, A. (2011). Determination of labour outputs for selected trades in the Nigerian construction industry. Unpublished B.Sc. Thesis, Department of Quantity Surveying, Ahmadu Bello University, Zaria.

Lawal A. and Adeyeye R. (2006), Benchmarking of construction productivity. Journal of Construction Engineering and Management,131(7): 772 - 778.

Muhammad, A. (2009). Empirical determination of labour outputs for selected trades in
Kaduna state, Unpublished B.Sc. Thesis, Department of Quantity Surveying, Ahmadu Bello University, Zaria.

Nalumansi, J., Mwesige, G. (2012). Determining productivity of masons for both stretcher and header bonding on building dites. Unpublished B.Sc. Dissertation, Department of Building, Makerere University, Kampala. Uganda

Nunnaly, S. W. (2005). Construction method and Management, $7^{\text {th }}$ Ed., London: Blackwell Publishing.

Ojo, S. O. (2009). An identification of clients' needs for building projects: A Nigerian Study, Journal of Environmental Design and Management, 2(1): 20- 30.

Polat, G. and Arditi, P. (2005). The JIT management system in developing countries. Construction Management and Economics, 23(7): 697-712.

Yu, J. and Lee, H. (2008). Productivity management system for construction projects, Journal of the Architectural Institute of Korea, 18(7): 103- 113. 